\title{
Down-Regulation of Endogenous Hydrogen Sulfide Pathway in Pulmonary Hypertension and Pulmonary Vascular Structural Remodeling Induced by High Pulmonary Blood Flow in Rats
}

\author{
Li Xiaohui, PhD; Du Junbao, MD; Shi Lin, PhD; Li Jian, MD*; Tang Xiuying, MD**; \\ Qi Jianguang, MD; Wei Bing, MD; Jin Hongfang, $\mathrm{PhD}$; Tang Chaoshu, $\mathrm{PhD}^{\dagger}$
}

\begin{abstract}
Background The mechanisms responsible for the development of pulmonary hypertension ( $\mathrm{PH}$ ) and pulmonary vascular structural remodeling induced by high pulmonary blood flow are not fully understood. The present study was designed to explore the possible changes in endogenous hydrogen sulfide $\left(\mathrm{H}_{2} \mathrm{~S}\right)$, a novel gasotransmitter, on the pathogenesis of $\mathrm{PH}$ and pulmonary vascular structural remodeling induced by high pulmonary blood flow.

Methods and Results Twenty-two male Sprague-Dawley rats were randomly divided into a shunting group $(n=11)$ and control group $(n=11)$. Rats in the shunting group underwent an abdominal aorta-inferior cava vein shunting operation. After 11 weeks of shunting, the plasma level of $\mathrm{H}_{2} \mathrm{~S}$ and lung tissue $\mathrm{H}_{2} \mathrm{~S}$ producing rate were much lower than those of the control group $(\mathrm{p}<0.01)$. In situ hybridization analysis showed that the expression of cystathioniney -lyase (CSE) mRNA was down-regulated in the pulmonary arteries of the shunting rats compared with the control group $(\mathrm{p}<0.01)$, and competitive quantitative reverse transcription-polymerase chain reaction showed that the relative amount of CSEmRNA in lung tissue was decreased significantly $(\mathrm{p}<0.01)$.

Conclusions The endogenous $\mathrm{H}_{2} \mathrm{~S}$ pathway is down-regulated in $\mathrm{PH}$ and pulmonary vascular structural remodeling is induced by high pulmonary blood flow. (Circ J 2005; 69: 1418-1424)
\end{abstract}

Key Words: High pulmonary blood flow; Hydrogen sulfide; Pulmonary hypertension; Pulmonary vascular structural remodeling

$\mathbf{P}$ ulmonary hypertension $(\mathrm{PH})$ is a common complication of congenital heart disease with a left-to-right shunt characterized by high pulmonary blood flow. Pulmonary vascular structural remodeling is an important pathologic consequence of $\mathrm{PH}$. To date, the mechanisms responsible for the induction of pulmonary vascular structural remodeling by increased pulmonary blood flow are still not fully understood. Some studies have demonstrated that high pulmonary blood flow produces high shear stress on pulmonary artery (PA) endothelial cells (ECs) and smooth muscle cells (SMCs), resulting in maladjustment of the maintenance of the structure and function of blood vessels, in which endogenous gasotransmitters, such as nitric oxide (NO) and carbon monoxide (CO), play important regulatory roles ${ }^{1-5}$ However, the molecular mechanisms of pulmonary vascular structural remodeling are still poorly understood, and researchers are seeking novel endogenously

(Received March 22, 2005; revised manuscript received August 3, 2005; accepted August 11, 2005)

Department of Pediatrics, Peking University First Hospital and Key Laboratory of Molecular Cardiovascular Sciences, Ministry of Education, *Department of Thoracic Surgery, Peking University First Hospital, **Laboratory of Electron Microscopy, Peking University First Hospital and Institute of Cardiovascular Research, Peking University First Hospital, Beijing, People's Republic of China

Mailing address: Du Junbao, MD, Department of Pediatrics, Peking University First Hospital, Xi-An Men Street No.1, West District, Beijing 100034, People's Republic of China. E-mail: junbaodu@ht. rol.cn.net (corresponding author) produced gasotransmitters to investigate their possible significance in the pathogenesis of pulmonary vascular structural remodeling. Recently, hydrogen sulfide $\left(\mathrm{H}_{2} \mathrm{~S}\right)$ was found to facilitate the induction of hippocampus long-time potentiation as a neuromodulator6 More interestingly, a previous study of ours demonstrated that $\mathrm{H}_{2} \mathrm{~S}$ was endogenously produced in the heart as well as in vessels ${ }^{7}$ and could inhibit the proliferation of cultured vascular SMCs in vitro, 89 Another of our studies also showed that the endogenous $\mathrm{H}_{2} \mathrm{~S}$ pathway was involved in the development of hypoxic $\mathrm{PH}(\mathrm{HPH})$ and that exogenous $\mathrm{H}_{2} \mathrm{~S}$ could attenuate the elevation of PA pressure and lessen pulmonary vascular structural remodeling during $\mathrm{HPH} !^{10}$ Based on those findings, the present study was designed to investigate the possible role of endogenous $\mathrm{H}_{2} \mathrm{~S}$ in the development of $\mathrm{PH}$ and pulmonary vascular structural remodeling induced by high pulmonary blood flow.

\section{Methods \\ Rat Model of High Blood Flow \\ Experiments were conducted in accordance with the Guide to The Care And Use of Experimental Animals issued by the Ministry of Health of the People's Republic of China. Male Sprague-Dawley (SD) rats weighing 150- $200 \mathrm{~g}$ were provided by the Animal Research Centre of Peking University First Hospital. They were kept in a tem- perature-controlled room with a $12 \mathrm{~h}$ light-dark cycle. Tap water and rat chow were provided ad libitum. The animal}


model of high blood flow was established by an abdominal aorta-inferior vena cava shunting operation performed according to the description by Garcia and Diebold,11 with some modifications! Briefly, 22 male SD rats were randomly divided into a shunting group $(n=11)$ and control group $(n=11)$. Rats in the shunting group were anesthetized using $0.25 \%$ pentobarbital sodium $(40 \mathrm{mg} / \mathrm{kg}$, ip). The abdominal aorta and inferior vena cava were exposed by opening the abdominal cavity via a midline incision. A bulldog vascular clamp was placed across the aorta caudal to the left renal artery. The aorta was punctured with an 18-gauge disposable needle at the union of the segment two-thirds caudal to the renal artery and one-third cephalic to the aortic bifurcation. The needle was advanced into the aorta at $45^{\circ}$, perforating its adjacent wall and penetrating the vena cava. Then the needle was slowly withdrawn and a 9-0 silk thread was used to suture the puncture. The clamp was removed $30 \mathrm{~s}$ later and the patency of the shunt was verified visually by the mixture of arterial and venous blood in the inferior vena cava. The peritoneal cavity was closed with silk thread and gentamycin was injected for the prevention of infection. In the control group, rats underwent the same experimental process but without the shunting operation.

\section{Measurement of Hemodynamic Parameters and Sample Preparation}

At the end of the experimental period, the animals were weighed and anesthetized with pentobarbital sodium $(40 \mathrm{mg} / \mathrm{kg}$, ip). A silicone catheter $(0.9 \mathrm{~mm}$ in outer diameter) was introduced under fluoroscopic guidance into the right jugular vein via a venotomy and passed across the tricuspid valve and right ventricle (RV) into the PA. The other end of the catheter was connected to a YZ-05-1 transducer (Beijing, China). The mean PA pressure (mPAP), systolic PAP (sPAP) and diastolic PAP were simultaneously recorded. After the chest was opened, the right lung was removed and placed in liquid nitrogen for rapid freezing and then stored at $-70^{\circ} \mathrm{C}$, and the lower left lung was removed and placed in $10 \%$ paraformaldehyde for fixation. Then the heart was removed and the RV and the left ventricle plus the septum $(\mathrm{LV}+\mathrm{SP})$ were dissected free. These tissues were blotted and weighed using an electronic scale. The ratio of the wet weight of the RV to that of the $\mathrm{LV}+\mathrm{SP}$ $[\mathrm{RV} /(\mathrm{LV}+\mathrm{SP})]$ was calculated as an indicator of RV hypertrophy. Plasma was collected from the rats, centrifuged and stored at $-70^{\circ} \mathrm{C}$ for the measurement of $\mathrm{H}_{2} \mathrm{~S}$ concentration.

\section{Morphological Analysis of the PAs}

The lung tissue fixed in $10 \%(\mathrm{w} / \mathrm{v})$ paraformaldehyde was dehydrated, embedded in paraffin, and sectioned at $4 \mu \mathrm{m}$. The elastic fiber in the lung tissues was stained according to the modified Weigert's method and re-stained with van Gieson solution. Morphological analysis was performed using a video-linked microscope digitizing board system (Leica Q550CM, Germany). Only vessels showing clearly defined external and internal elastic lamina were included in the analysis. The relative medial thickness (RMT) and relative medial areas (RMA) were calculated according to Barth et al's method.2

A small section of lung tissue was cut from the upper part of the left lobe and quickly immersed in $3 \%$ glutaraldehyde, after which it was cut into pieces $1 \times 1 \times 1 \mathrm{~mm}$ in size and post-fixed in $1 \%$ phosphate-buffered osmium tetroxide for $6 \mathrm{~h}$. The samples were rinsed again (overnight) and dehydrated in a graded series of ethanol, before being infiltrated with propylene oxide and embedded with Epon 812. These procedures were all done at room temperature. Finally, the specimens were embedded in new batches of Epon 812 and polymerized at $40^{\circ} \mathrm{C}(24 \mathrm{~h})$ and $60^{\circ} \mathrm{C}(48 \mathrm{~h})$. From selected blocks, series of transverse or longitudinal sections were made. Semi-thin sections $(1 \mu \mathrm{m})$ were stained with azur-II and methylene blue. Ultra-thin sections (60$90 \mathrm{~nm}$ ) were cut with an ultra-microtome and mounted on formvar-coated copper grids (75 meshes), for staining with uranylacetate and lead citrate, and examination under a transmission electron microscope (JEM-100CX, JEOL, Japan).

\section{Measurement of Plasma $\mathrm{H}_{2} \mathrm{~S}$ Concentration}

A sample of plasma $(0.1 \mathrm{ml})$ was added to a test tube containing $0.5 \mathrm{ml}$ of $1 \%$ zinc acetate and $2.5 \mathrm{ml}$ of distilled water, then $0.5 \mathrm{ml}$ of $20 \mathrm{mmol} / \mathrm{L} \mathrm{N}, \mathrm{N}$-dimethyl-p-phenylenediamine dihydrochloride in $7.2 \mathrm{~mol} / \mathrm{L} \mathrm{HCl}$ and $0.4 \mathrm{ml}$ of $30 \mathrm{mmol} / \mathrm{L} \mathrm{FeCl} 3$ in $1.2 \mathrm{~mol} / \mathrm{L} \mathrm{HCl}$ were also added to the same test tube for $20 \mathrm{~min}$ of incubation at room temperature. The protein in the plasma was removed by adding $1 \mathrm{ml}$ of $10 \%$ trichloroacetic acid to the solution and centrifuging it. The optical absorbance of the resulting solution at $670 \mathrm{~nm}$ was measured with a spectrometer (Shimadzu UV 2100 , Japan). $\mathrm{H}_{2} \mathrm{~S}$ concentration in the solution was calculated against the calibration curve of the standard NaHS solution.

\section{Measurement of Tissue $\mathrm{H}_{2} \mathrm{~S}$ Production Rate}

Tissue $\mathrm{H}_{2} \mathrm{~S}$ production rate was measured using the method of chemical catalytic reaction.11 The right lung was homogenized in ice-cold $50 \mathrm{mmol} / \mathrm{L}$ potassium phosphate buffer ( $\mathrm{pH}$ 6.8). Reactions were performed in a $25 \mathrm{ml}$ Erlenmeyer flask. The reaction mixture contained (mmol/L): 10 L-cysteine, 2 pyridoxal 5'-phosphate, 100 potassium phosphate buffer ( $\mathrm{pH} 7.4)$, and $10 \%(\mathrm{w} / \mathrm{v})$ homogenates. The total volume of the reaction mixture was $1 \mathrm{ml}$. A small piece of filter paper was put into the central well of the flask and $0.5 \mathrm{ml}$ of $1 \%$ zinc acetate was also added to trap evolving $\mathrm{H}_{2} \mathrm{~S}$ in the mixture. The flask was then flushed with $\mathrm{N}_{2}$ before being sealed with a double layer of parafilm. The catalytic reaction was initiated by transferring the flask from an ice bath to a $37^{\circ} \mathrm{C}$ shaking water bath. After $90 \mathrm{~min}$, the reactions were stopped by injecting $0.5 \mathrm{ml}$ of $50 \%$ trichloroacetic acid. The flask was incubated in the shaking water bath at $37^{\circ} \mathrm{C}$ for an additional hour to complete the trapping of $\mathrm{H}_{2} \mathrm{~S}$. The content of the central well was transferred to test tubes and mixed with $3.5 \mathrm{ml}$ of distilled water and $0.5 \mathrm{ml}$ of $20 \mathrm{~mol} / \mathrm{L} \mathrm{N}, \mathrm{N}$-dimethyl-ppheny-lenediamine dihydrochloride in $7.2 \mathrm{~mol} / \mathrm{L} \mathrm{HCl}$. To each tube, $0.4 \mathrm{ml}$ of $30 \mathrm{mmol} / \mathrm{L} \mathrm{FeCl}_{3}$ in $1.2 \mathrm{~mol} / \mathrm{L} \mathrm{HCl}$ was added immediately. After $20 \mathrm{~min}$ of incubation at room temperature, the optical absorbance of the resulting solution at $670 \mathrm{~nm}$ was measured with a spectrometer (Shimadzu UV 2001). The $\mathrm{H}_{2} \mathrm{~S}$ concentration in the solution was calculated against the calibration curve of the standard $\mathrm{NaHS}$ solution for each sample and the measurement was done in duplicate. The $\mathrm{H}_{2} \mathrm{~S}$ producing rate was expressed as $\mathrm{nmol} / \mathrm{mg} \cdot$ wet $\cdot$ tissue/min.

\section{Expression of Cystathioniney -Lyase (CSE) mRNA in Lung Tissue by In Situ Hybridization}

The upper part of the left lung fixed in $10 \%(\mathrm{w} / \mathrm{v})$ par- 
Table 1 Changes in the Hemodynamic Parameters and Right Ventricle (RV) Hypertrophy in Rats

\begin{tabular}{lcccccc}
\hline \hline Group & $n$ & $\begin{array}{c}s P A P \\
(\mathrm{mmHg})\end{array}$ & $\begin{array}{c}d P A P \\
(\mathrm{mmHg})\end{array}$ & $\begin{array}{c}m P A P \\
(\mathrm{mmHg})\end{array}$ & $\begin{array}{c}R V / B W \\
(\mathrm{~g} / \mathrm{kg})\end{array}$ & $\begin{array}{c}R V /(L V+S) \\
(g / g)\end{array}$ \\
\hline Control & 11 & $25.02 \pm 3.31$ & $9.15 \pm 3.02$ & $15.86 \pm 1.92$ & $0.48 \pm 0.08$ & $0.22 \pm 0.01$ \\
Shunt & 11 & $34.53 \pm 2.62 *$ & $10.13 \pm 3.41$ & $23.64 \pm 2.21 *$ & $0.80 \pm 0.17 *$ & $0.27 \pm 0.02 *$ \\
\hline
\end{tabular}

Data are mean $\pm S D$.

sPAP, systolic pulmonary artery pressure; dPAP, diastolic pulmonary artery pressure; mPAP, mean pulmonary artery pressure; $R V / B W$, wet weight of right ventricle/basal weight; $R V /(L V+S P)$, wet weight of right ventricle/left ventricle + septum.

$* p<0.01$ vs control group.

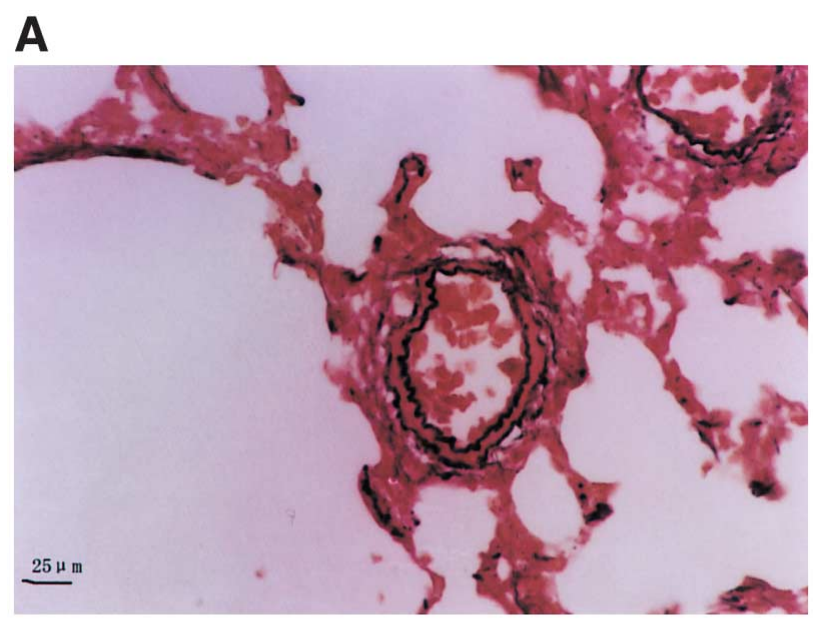

B

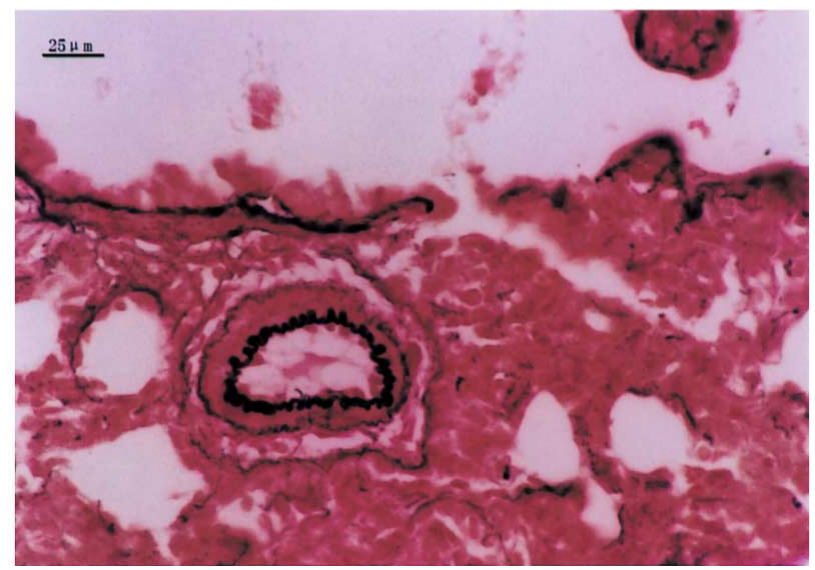

Fig 1. (A) Pulmonary muscular artery (MA) in a control rat (Hart's elastic fibers staining +VG staining, $\times 400$ ). (B) Pulmonary MA in a rat from the shunt group, showing the thickened medial layer (Hart's elastic fibers staining + VG staining, $\times 400)$. VG, van Gieson.

aformaldehyde was dehydrated, embedded in paraffin, and sectioned at $5 \mu \mathrm{m}$. After being dewaxed and hydrated routinely, the sections were blocked in $\mathrm{H}_{2} \mathrm{O}_{2}$ for 10 min at room temperature, and digested in $3 \%$ citrate solution for $10-15 \mathrm{~min}$ at $37^{\circ} \mathrm{C}$. Then they were washed in 0.5 phosphate-buffered saline (PBS) for 5 min 3 times and in distilled water once. Each section had $20 \mu 1$ of labeled probe with oligonucleotide added, and was then covered with film for hybridization for $120 \mathrm{~min}$ at $37-40^{\circ} \mathrm{C}$. Later, the film was removed, and the section was washed for $5 \mathrm{~min} 3$ times in $2 \times$ standard salin citrate (SSC) solution at $30-37^{\circ} \mathrm{C}$. The sections were stabilized with hybridization probe for $20 \mathrm{~min}$ at $37-40^{\circ} \mathrm{C}$ and were washed for 5 min 3 times in $2 \times \mathrm{SSC}$ solution. After the sections were blocked in blocking solution for $20 \mathrm{~min}$ at $37^{\circ} \mathrm{C}$, and rabbit-anti-DIG was added for $60 \mathrm{~min}$ at $37^{\circ} \mathrm{C}$, they were washed for 2 min 3 times in $0.5 \mathrm{~mol} / \mathrm{L} \mathrm{PBS}$. Again, goat-anti-rabbit-biotin $\mathrm{IgG}$ was added to sections for $20 \mathrm{~min}$ at $37^{\circ} \mathrm{C}$, after which the sections were washed for $2 \mathrm{~min} 3$ times in $0.5 \mathrm{~mol} / \mathrm{L}$ PBS solution. Finally, SABC was added to the sections for $20 \mathrm{~min}$ at $37^{\circ} \mathrm{C}$, after which they were washed for $5 \mathrm{~min}$ 4 times in $0.5 \mathrm{~mol} / \mathrm{L}$ PBS. The color was developed using DAB- $\mathrm{H}_{2} \mathrm{O}_{2}$ for $20 \mathrm{~min}$ before the sections were stained with hematoxylin.

Endogenous $\mathrm{H}_{2} \mathrm{~S}$ is generated from thio-containing amino acids in a reaction catalyzed by cystathionine $\beta$ systhase (CBS) and CSE. In the present study, brown granules in the cell nucleus was defined as the expression of CSE mRNA, the intensity of which was determined semiquantitatively: negative $(-)$ if there was no positive signal in the PA cells; (+) if $1-50 \%$ of cells showed a positive signal; (++) if $51-100 \%$ of cells were positive. At least 10 medial and small PAs were examined, respectively, for each slide. For the convenience of interpretation and statistical analysis, the CSE mRNA content of PAs was expressed as integral scores: the percentage of PAs with a certain extent of reaction intensity was multiplied by the weighted values of their reaction intensity. The weighted value of the reaction intensity was $0,0.5$ and 1.0 , if the reaction intensity was,-+ and ++ , respectively 13

\section{Measurement of CSE mRNA in Lung Tissue by Competitive Quantitative Reverse Transcription-Polymerase Chain Reaction (RT-PCR)}

Total RNA was extracted from rat lung tissue using Trizol reagent. The cDNA was synthesized using an oligo (dT)15 primer and M-MLV reverse transcriptase. The polymerase chain reaction (PCR) primers used to amplify the fragment of CSE cDNA were 5'-TCCGG ATGGA GAAAC ACTTC for CSE-S and 5'-GCTGC CTTTA AAGCT TGACC for CSE-A.

With these primers PCR yielded a $400 \mathrm{bp}$ fragment of wild-type rat CSE cDNA. The competitive internal standard for the measurement of CSE cDNA had the same sequences as the $400 \mathrm{bp}$ fragment of wild-type rat CSE cDNA, except that a $39 \mathrm{bp}$ fragment at the downstream site of the CSE-S primer was deleted according to the methods described by Siebert and Carrick ${ }^{13}$ and Sambrook and Russell. ${ }^{4}$ Wild-type rat CSE cDNA in the sample and the internal standard were competitively amplified in the same PCR system. Quantitative PCR was performed in a $0.2 \mathrm{ml}$ PCR tube containing $1 \mu 1$ of rat lung cDNA, $1 \mu 1$ of $3.9 \mathrm{fmol} / \mathrm{L}$ competitive internal standard, $1 \mu 1$ of $5 \mu \mathrm{mol} / \mathrm{L}$ of each CSE-S and CSE-A mixture, $1 \mu \mathrm{mol} / \mathrm{L}$ of each $\mathrm{dNTP}$ polymerase, in a total volume of $25 \mu 1$. PCR products were separated on $2 \%$ agarose gel and stained with ethid- 
Table 2 Percentage of 3 Types of Small Pulmonary Blood Vessels, and the RMT and RMA of the Pulmonary Arteries in Rats

\begin{tabular}{|c|c|c|c|c|c|c|c|c|}
\hline & \multirow{2}{*}{$n$} & \multicolumn{3}{|c|}{ Small pulmonary blood vessels (\%) } & \multicolumn{2}{|c|}{$R M T$} & \multicolumn{2}{|c|}{$R M A$} \\
\hline & & $M A$ & $P M A$ & $N M A$ & $M P A$ & $S P A$ & $M P A$ & $S P A$ \\
\hline Control & 11 & $13.62 \pm 1.82$ & $14.73 \pm 1.72$ & $71.76 \pm 2.63$ & $5.72 \pm 0.33$ & $7.54 \pm 0.75$ & $9.32 \pm 1.73$ & $13.53 \pm 1.21$ \\
\hline Shunt & 11 & $23.28 \pm 3.13 *$ & $23.95 \pm 3.23$ & $52.85 \pm 6.02 *$ & $7.76 \pm 0.62 *$ & $11.78 \pm 1.02 *$ & $14.56 \pm 1.12 *$ & $22.26 \pm 2.13 *$ \\
\hline
\end{tabular}

Data are mean $\pm S D$.

RMT, relative medial thickness; RMA, relative medial area; MA, muscular artery; PMA, partly muscular artery; NMA, non-muscular artery; MPA, medial pulmonary artery; SPA, small pulmonary artery.

${ }^{*} p<0.01$ vs control group.
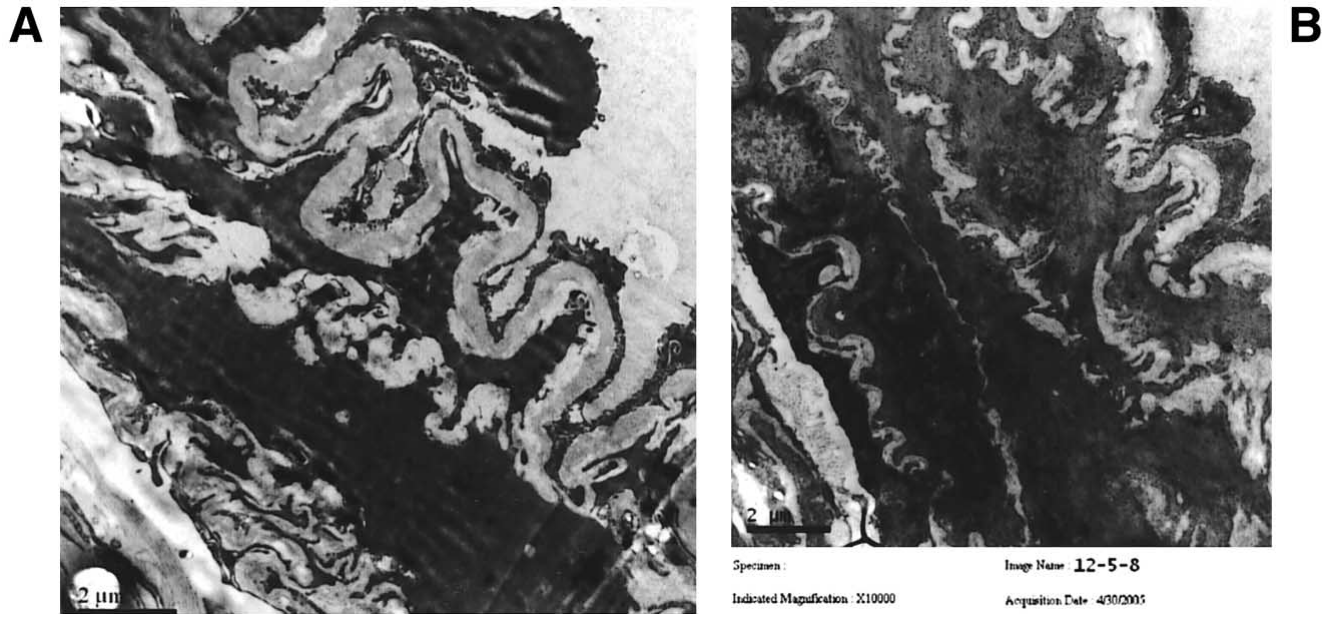

Fig 2. Ultrastructure of a pulmonary artery in (A) control rat showing the flat endothelial cells (ECs), regular internal elastic lamina and cytoplasm of the smooth muscle cells full of myofilaments and dense bodies. (B) Rat from the shunt group showing swollen and hypertrophic ECs, irregular internal elastic lamina and increased rough endoplasmic reticulum and free ribosomes in the cytoplasm of smooth muscle cells $(\mathrm{A}, \mathrm{B}: \times 10,000)$.

ium bromide. The ratio of the optical density of the 2 DNA bands was measured using a Gel Image Analysis System (AlphaImager, Alpha Innotech, CA, USA) under UV light. A standard curve of the ratio was drawn under the same conditions as described except that rat lung cDNA was changed for a series of dilutions of a plasmid containing the $400 \mathrm{bp}$ wild-type CSE cDNA fragment. The relative amount of CSE cDNA in the samples was then obtained from the standard curve. To calibrate the amount of sample loaded into the PCR mixture, $\beta$-actin cDNA was measured using the same method: $3 \mu 1$ of PCR product was amplified again using 2 rat $\beta$-actin primers $\beta$-actin-S: 5'-ATCTG GCACC ACACC TTC; $\beta$-actin-A: 5'-AGCCA GGTCC AGACG CA). The relative amount of $\beta$-actin cDNA in the loaded sample was then obtained from an established standard curve of $\beta$-actin cDNA measurement and the standard relative amount of CSE cDNA was used for further analysis.

\section{Chemicals and Reagents}

NaHS solution was freshly prepared by mixing stock solutions of sodium sulfide and hydrochloric acid. Phosphate 5'-pyridoxal was purchased from Sigma Corporation (St Louis, MO, USA); Trizol reagent from Invitrogen (San Diego, CA, USA), and oligo (dT)15 primer, dNTP, and MMLV reverse transcriptase from Beijing Chemical Reagents. Hybridization kits were purchased from Zhongshan Biological Technique Ltd (Beijing, China).

\section{Data Analysis}

The results were expressed as mean \pm SD SPSS 10.0 statistical analysis software was used to compare the difference between 2 groups ( $\mathrm{t}$-test), and a value of $\mathrm{p}<0.05$ was considered statistically significant.

\section{Results}

\section{Hemodynamic Parameters}

After 11 weeks of shunting, the sPAP and mPAP increased significantly compared with the control group $(p<0.01)$ (Table 1). The ratios of the wet weight of the RV to basal weight (RV/BW) and the wet weight of RV/LV+ SP, indicators of RV hypertrophy, also increased markedly in the rats of shunting group compared with those of the control group $(\mathrm{p}<0.01)$ (Table 1$)$.

\section{Morphological Analysis of the PAs}

Compared with the control rats, the RMT and RMA, which were defined as parameters of pulmonary vascular structural remodeling, were increased significantly in medial and small PAs, together with the development of $\mathrm{PH}$ in the shunting rats $(\mathrm{p}<0.01)$ (Fig 1$)$. In addition, among the small pulmonary blood vessels in the shunting rats the percentage of muscular artery (MA) and partly MA (PMA) increased significantly and the percentage of non-MA (NMA) decreased significantly $(\mathrm{p}<0.01)$ (Table 2$)$. Furthermore, the ECs were swollen and hypertrophic, the internal elastic lamina appeared irregular, and rough endoplasmic reticulum and free ribosomes increased in cytoplasm of SMCs in these rats (Fig 2). 
Table 3 Changes in the Plasma Level of $\mathrm{H}_{2} \mathrm{~S}$, Lung Tissue $\mathrm{H}_{2} \mathrm{~S}$ Production Rate, and the Amount of CSE mRNA in the Lung Tissues of Rats

\begin{tabular}{lcccc}
\hline \hline Group & $n$ & $\begin{array}{c}\text { Plasma level of } \mathrm{H}_{2} \mathrm{~S} \\
(\mathrm{\mu} \text { mol/L) }\end{array}$ & $\begin{array}{c}\mathrm{H}_{2} \text { S production rate } \\
(\text { nmol/mg wet tissue min })\end{array}$ & $\begin{array}{c}\text { CSE mRNA } \\
(10-3 f m o l / L)\end{array}$ \\
\hline Control & 11 & $50.83 \pm 4.01$ & $0.26 \pm 0.02$ & $6.84 \pm 2.11$ \\
Shunt & 11 & $36.42 \pm 3.12 *$ & $0.13 \pm 0.02 *$ & $2.30 \pm 1.07 *$ \\
\hline
\end{tabular}

Data are mean $\pm S D$.

$\mathrm{H}_{2} \mathrm{~S}$, hydrogen sulfide; CSE, cystathioniney -lyase.

$* p<0.01$ vs control group.

Table 4 Integral Scores of CSE mRNA Expression by Pulmonary Artery Smooth Muscle Cells in Rats

\begin{tabular}{lcc}
\hline \hline Group & $\begin{array}{c}\text { Medial pulmonary } \\
\text { arteries }\end{array}$ & $\begin{array}{c}\text { Small pulmonary } \\
\text { arteries }\end{array}$ \\
\hline Control & $40.95 \pm 4.93$ & $35.05 \pm 7.72$ \\
Shunting & $25.92 \pm 4.95^{*}$ & $20.92 \pm 4.93^{*}$ \\
\hline
\end{tabular}

CSE, cystathionineY -lyase.

$* p<0.01$ vs control group.

\section{Measurement of Plasma $\mathrm{H}_{2} \mathrm{~S}$ Concentration}

The plasma level of $\mathrm{H}_{2} \mathrm{~S}$ and the $\mathrm{H}_{2} \mathrm{~S}$ production rate in the shunting group were both much lower than those of the rats in the control group $(\mathrm{p}<0.01)($ Table 3$)$.

\section{Expression of CSE mRNA in Lung Tissue by In Situ Hybridization}

CSEmRNA expression was obviously down-regulated in the SMCs of the PAs of shunt rats as compared with those of control rats (Table 4, Fig 3).

\section{Measurement of CSE mRNA in Lung Tissue by Competitive Quantitative RT-PCR}

In contrast to the control group, the relative amount of CSE mRNA in the lung tissue of the shunting group was decreased significantly $(\mathrm{p}<0.01)$ (Fig 4$)$.

\section{Discussion}

$\mathrm{PH}$ is an important pathophysiological process in a variety of cardiovascular and pulmonary diseases, and it directly affects the development of the diseases and their prognosis. Pulmonary vascular structural remodeling is a remarkable pathologic consequence of $\mathrm{PH}, 15,16$ but the cellular and molecular mechanisms are not fully understood.

The results of the present study showed that abdominal aorta-cava shunting for 11 weeks successfully induced PH
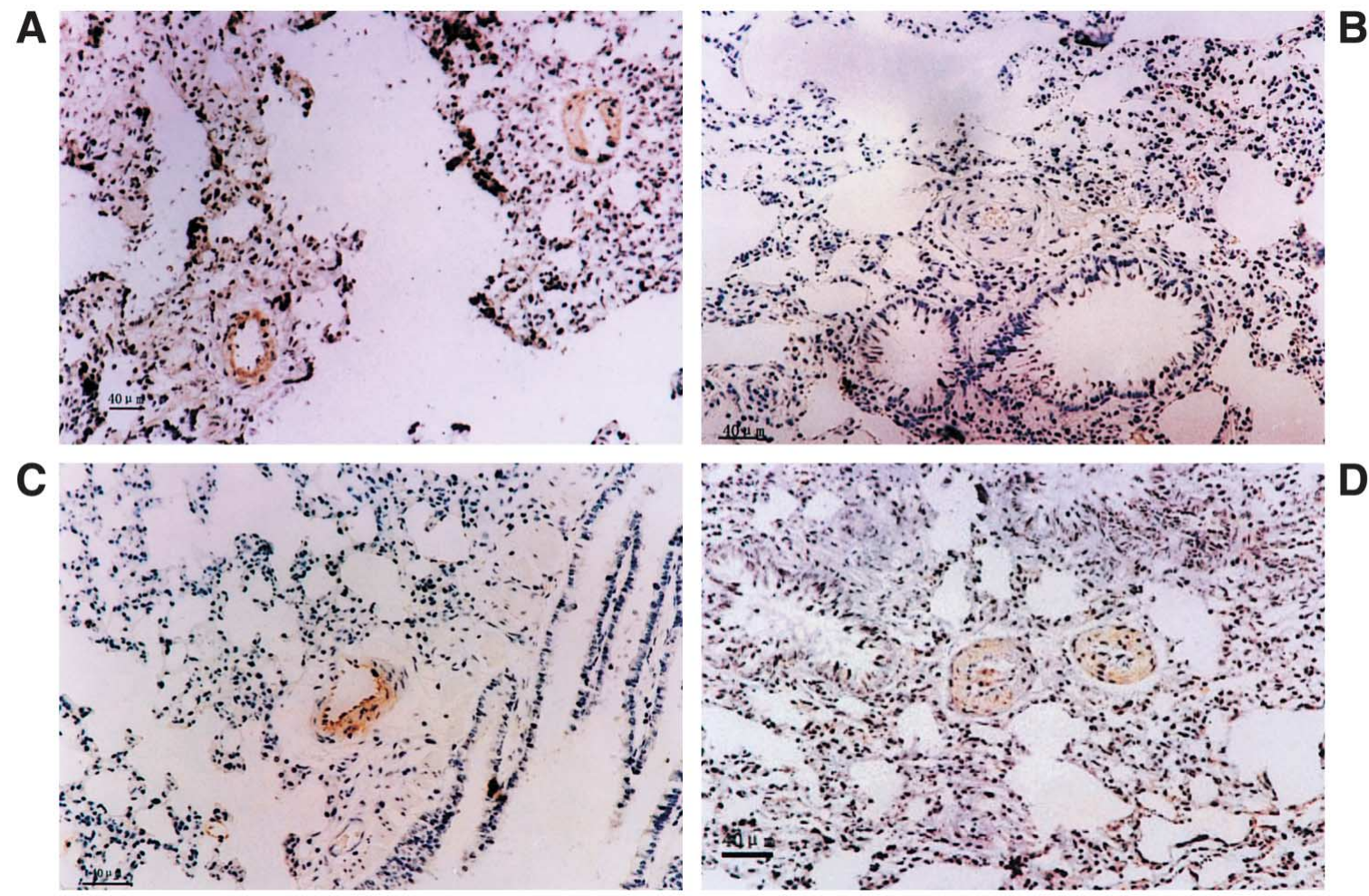

Fig 3. In situ hybridization showing (A) positive CSE mRNA expression (++) localized in smooth muscle cells of small pulmonary muscular arteries and minimal expression in pulmonary vascular endothelial cells (ECs) in a control rat. (B) Negative CSE mRNA expression (-) in both smooth muscle cells and ECs of a small pulmonary muscular artery (MA) in a rat from the shunt group. (C) Positive CSE mRNA expression (++) localized in the smooth muscle cells of a medial pulmonary MA from a control rat $(\mathrm{DAB}, \times 250)$. (D) Positive CSE mRNA expression $(+)$ in the smooth muscle cells and ECs of a medial pulmonary MA in a rat from the shunt group. CSE, cystathioniney -lyase (A-D: DAB, $\times 250$ ). 
and pulmonary vascular structural remodeling. The sPAP and mPAP of shunt rats increased significantly compared with those in the control group. The ratios of RV/BW and $\mathrm{RV} / \mathrm{LV}+\mathrm{SP}$, indicators of RV hypertrophy, also increased in rats with high pulmonary blood flow. In this study, we defined medial PAs as those with an outer diameter ranging from 50 to $150 \mathrm{\mu} \mathrm{m}$, and small PAs as those with an outer diameter ranging from 15 to $50 \mu \mathrm{m}$. The results demonstrated that after 11 weeks of shunting, the percentage of MA and PMA increased and the percentage of NMA decreased significantly in small pulmonary vessels of shunting rats. Furthermore, we observed that the RMT and RMA of MA increased significantly in medial and small PAs with the development of $\mathrm{PH}$. Ultrastructural examination showed that ECs were swollen and hypertrophic, the internal elastic lamina appeared irregular, and rough endoplasmic reticulum and free ribosomes increased in the cytoplasm of SMCs. These findings indicate that $\mathrm{PH}$ and pulmonary vascular structural remodeling developed in rats after 11 weeks of aorta-caval shunting, which was in accordance with our previous study!

Although numerous humoral factors in the development of $\mathrm{PH}$ and pulmonary vascular structural remodeling in left-to-right shunt congenital heart diseases have been investigated, the mechanisms responsible for pulmonary vascular structural remodeling induced by high pulmonary blood flow are still not fully understood. The discovery of endogenous gasotransmitters, such as NO and CO, has moved research into these conditions to a very new phase ${ }^{17,18}$ As gas molecules, NO and CO are characterized by continuous generation, fast transmission and easy passage through biological membrane under pathophysiological or physiological conditions.

$\mathrm{H}_{2} \mathrm{~S}$ has been known for decades as a toxic gas in water pollution and industrial air pollution with a strong odor of rotten eggs, but it was only recently that researchers came to understand $\mathrm{H}_{2} \mathrm{~S}$ as a novel gasotransmitter playing an important biological role, especially in the cardiovascular system. ${ }^{19-22}$ In rats, endogenous $\mathrm{H}_{2} \mathrm{~S}$ is generated from thiocontaining amino acids in a reaction catalyzed by CBS and CSE. CBS is highly expressed in the brain, and CSE is rich in the wall of the PAs, aorta, tail arteries, mesenteric arteries and portal vein. In mammalian tissues $\mathrm{H}_{2} \mathrm{~S}$ may be a physiological regulator in the nervous system and cardiovascular system,23,24 with its vascular effect possibly mediated by the opening of the KATP channel of vascular tissues 25 Importantly, we recently reported that $\mathrm{H}_{2} \mathrm{~S}$ could inhibit SMC proliferation, and it has also been reported that the $\mathrm{H}_{2} \mathrm{~S}$ concentration of rat serum was $45.6 \pm 14.2 \mu \mathrm{mol} / \mathrm{L}$, which exerted an important biological effect in a dosedependent manner.23 Our research group first reported that the endogenous $\mathrm{H}_{2} \mathrm{~S}$ synthase $/ \mathrm{H}_{2} \mathrm{~S}$ pathway participated in a variety of vascular diseases including in the pathogenesis of spontaneous hypertension, HPH and pulmonary vascular structural remodeling, which suggests that $\mathrm{H}_{2} \mathrm{~S}$ is an important regulatory factor in cardiovascular physiological and pathophysiological processes $9,10,26$

In the present study of the possible significance of endogenous $\mathrm{H}_{2} \mathrm{~S}$ in left-to-right shunt rats with $\mathrm{PH}$ and pulmonary vascular structural remodeling induced by high pulmonary blood flow, the plasma level of $\mathrm{H}_{2} \mathrm{~S}$ and $\mathrm{H}_{2} \mathrm{~S}$ production rate in the shunting group were much lower than those of the control rats. Furthermore, the expression of CSE mRNA in the lung tissues of the shunt rats was decreased significantly, which suggests that CSE expres-

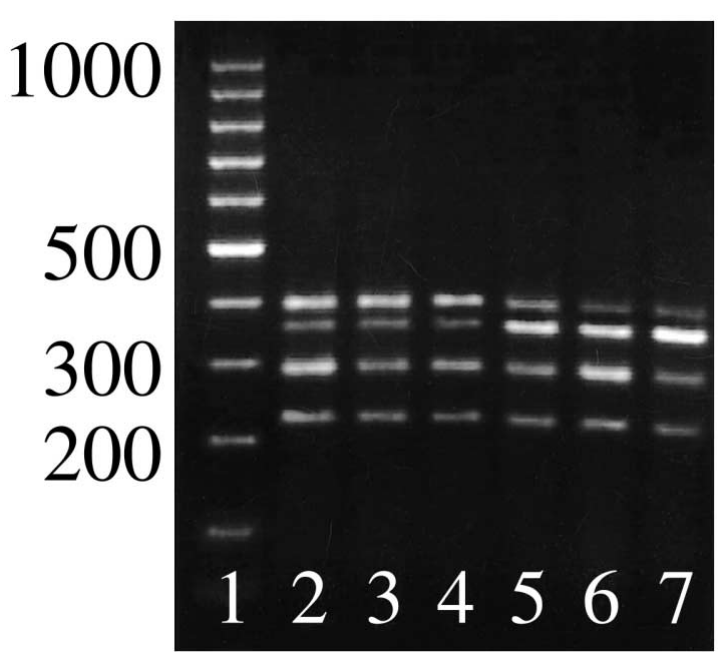

Fig 4. Electrophoregram of CSE mRNA in the pulmonary tissue of each group. 1-3, control group; 4-6 shunting group. Every lane has 4 bands, of which the 2 former bands are the CSE cDNA (400 bp) sample and CSE internal control ( $361 \mathrm{bp}$ ), and the 2 latter bands are $\beta$-actin cDNA and the $\beta$-actin internal control. CSE, cystathioniney lyase.

sion is downregulated in $\mathrm{PH}$ with pulmonary vascular structural remodeling. We used in situ hybridization for CSE localization and CSE mRNA expression was obviously downregulated in the SMCs of the pulmonary vasculature of shunt rats as compared with control rats. We also found that CSE mRNA was expressed mainly by the SMCs of the PAs, not by the ECs. Summarizing these findings, we found that there was downregulation of the $\mathrm{H}_{2} \mathrm{~S} / \mathrm{CSE}$ pathway in the PAs of rats with PH and pulmonary vascular structural remodeling induced by the high pulmonary blood flow.

Taken together, the evidence to date suggests that downregulation of the endogenous $\mathrm{H}_{2} \mathrm{~S} / \mathrm{CSE}$ pathway might be significant in the development of $\mathrm{PH}$ and pulmonary vascular structural remodeling. However, further studies using propagylglycine, an inhibitor of CSE, are needed to clarify the possible role of $\mathrm{H}_{2} \mathrm{~S} / \mathrm{CSE}$ pathway in the pathogenesis of this condition.

\section{Acknowledgments}

This work was supported by the Natural Science Foundation of Beijing, PR China (7052043), National Natural Science Foundation of China (30425010), and State Major Basic Research Project of China (G2000056905).

\section{References}

1. Wei B, Du JB, Qi JG, Li J, Tang CS. L-Arginine impacts pulmonary vascular structure in rats with an aortocaval shunt. J Surg Res 2002; 108: $20-31$.

2. Campbell AI, Kuliszewski MA, Stewart DJ. Cell-based gene transfer to the pulmonary vasculature: Endothelial nitric oxide synthase overexpression inhibits monocrotaline-induced pulmonary hypertension. Am J Respir Cell Mol Biol 1999; 21: 567-575.

3. Christou H, Morita T, Hsieh CM, Koike H, Arkonac B, Perrella MA, et al. Prevention of hypoxia-induced pulmonary hypertension by enhancement of endogenous heme oxygenase- 1 in the rat. Circ Res 2000; 86: $1224-1229$.

4. Kourembanas S. Hypoxia and carbon monoxide in the vasculature. Antioxidant Redox Signal 2002; 4: 291-299.

5. Minamino T, Christou H, Hsieh CM, Liu Y, Dhawan V, Abraham NG, et al. Targeted expression of heme oxygenase-1 prevents the pulmonary inflammatory and vascular responses to hypoxia. Proc Ntl Acad Sci USA 2001; 98: 8798-8803. 
6. Kimura H. Hydrogen sulfide as a neuromodulator. Mol Neurobiol 2002; 26: $13-19$

7. Zhao W, Wang R. $\mathrm{H}_{2} \mathrm{~S}$-induced vasorelaxation and underlying cellular and molecular mechanisms. Am J Physiol Heart Circ Physiol 2002; 283: H474-H480.

8. Dombkowski RA, Russell MJ, Olson KR. Hydrogen sulfide as an endogenous regulator of vascular smooth muscle tone in trout. Am J Physiol Regul Integr Comp Physiol 2004; 286: R678-R685.

9. Du JB, Yan H, Zhang ChY, Geng B, Jiang H, Ch XB, et al. The possible role of hydrogen sulfide as a smooth muscle cell proliferation inhibitor in rat cultured cells. Heart Vessels 2004; 19: 75-80.

10. Zhang CY, Du JB, Bu DF, Yan H, Tang XY, Tang CS. The regulatory effect of hydrogen sulfide on hypoxic pulmonary hypertension in rats. Biochem Biophys Res Commun 2003; 302: 810-816.

11. Garcia R, Diebold S. Simple, rapid, and effective method of producing aortocaval shunts in the rat. Cardiovasc Res 1990; 24: 430-432.

12. Barth PJ, Kimpel C, Roy S, Wagner U. An improved mathematical approach for the assessment of the medial thickness of pulmonary arteries. Pathol Res Pract 1993; 189: 567-576.

13. Siebert PD, Larrick JW. Competitive PCR. Nature 1992; 395: $557-$ 558.

14. Sambrook J, Russell DW. Molecular cloning: A laboratory manual, 3rd edn, Vol. 2. Cold Spring Harbor Laboratory Press; 2001; 8.868.89 .

15. Egito ES, Aiello VD, Bosisio IB, Lichtenfels AJ, Horta AL, Saldiva $\mathrm{PH}$, et al. Vascular remodeling process in reversibility of pulmonary arterial hypertension secondary to congenital heart disease. Pathol Res Pract 2003; 199: 521 - 532 .

16. Granton JT, Rabinovitch M. Pulmonary arterial hypertension in congenital heart disease Cardiol Clin 2002; 20: 441-457.
17. Vachharajani TJ, Work J, Issekutz AC, Granger DN. Heme oxygenase modulates selectin expression in different regional vascular beds. Am J Physiol Heart Circ Physiol 2000; 278: H1613-H1617.

18. Qi J, Du J, Tang X, Li J, Wei B, Tang C. The upregulation of endothelial nitric oxide synthase and urotensin-II is associated with pulmonary hypertension and vascular diseases in rats produced by aortocaval shunting. Heart Vessels 2004, 19: 81-88.

19. Hosoki R, Matsuki N, Kimura H. The possible role of hydrogen sulfide as an endogenous smooth muscle relaxant in synergy with nitric oxide. Biochem Biophys Res Commun 1997; 237: 527-531.

20. Abe K, Kimura $\mathrm{H}$. The possible role of hydrogen sulfide as an endogenous neuromodulator. J Neurosci 1996; 16: 1066-1071.

21. Du JB, Chen XB, Geng B, Jiang HF, Tang CS. Hydrogen sulfide as a messenger molecule in cardiovascular system. J Peking University (Health Sci) 2002; 34: 187

22. Fujii K, Sakuragawa T, Kashiba M, Sugiura Y, Kondo M, Maruyama $\mathrm{K}$, et al. Hydrogen sulfide as an endogenous modulator of biliary bicarbonate excretion in the rat liver. Antioxidant Redox Signal 2005; 7: $788-794$.

23. Wang R. Two's company, three's a crowd: $\mathrm{Can} \mathrm{H}_{2} \mathrm{~S}$ be the third endogenous gaseous transmitter? FASEB J 2002; 16: 1792-1798.

24. Kimura H, Nagai Y, Umemura K, Kimura Y. Physiological roles of hydrogen sulfide: Synaptic modulation, neuroprotection, and smooth muscle relaxation. Antioxidant Redox Signal 2005; 7: 795-803.

25. Zhao W, Zhang J, Lu Y, Wang R. The vasorelaxant effect of $\mathrm{H}_{2} \mathrm{~S}$ as a novel endogenous gaseous KATP channel opener. EMBO J 2001; 20: $6008-6016$.

26. Yan H, Du JB, Tang CS. The possible role of hydrogen sulfide on the pathogenesis of spontaneous hypertension in rats. Biochem Biophys Res Commun 2004; 313: 22-27. 